\title{
Habitat selection and activity patterns of female mule deer in the Front Range, Colorado
}

\author{
ROLAND C. KUFELD, DAVID C. BOWDEN, AND DONALD L. SCHRUPP
}

\section{Abstract}

Twenty-two adult, female mule deer (Odocoileus hemionus hemionus) were radio-collared with activity sensors and monitored with ground triangulation from mid-November through March, for 3 years (1982-1985) in the foothills west of Fort Collins, Colorado, to test 4 general hypotheses about habitat selection and activity: (1) The proportion of time deer spend feeding and resting varies with time of day. (2) Deer alter their activity patterns in response to environmental influences. (3) Selection of specific vegetation types for feeding and resting varies with time of day. (4) Ecotones are preferred habitats. Deer were monitored during 6-hr sampling perlods: sunrise, daytime, sunset, and night. Deer fed most during sunset, night, and sunrise periods and least during the day. Feeding occupied similar proportions of an average deer's time during sunset, night, and sunrise periods. They preferred the grassland type for feeding and resting at night and the mountain mahogany (Cercocarpus montanus) type for both activities during all other periods. Preference deer showed for the ponderosa pine (Pinus ponderosa) type for feeding activity was inversely related to canopy cover. Deer rested most during daytime and night periods. During periods of daylight, deer using the grassland type showed preference for ecotones with certain types offering escape cover. No such preference was observed at night. Deer fed less and rested more when snow depth exceeded $36 \mathrm{~cm}$. No significant differences $(P>0.05)$ in the proportion of time deer devoted to feeding were found in the following comparisons: clear versus cloudy full-moon nights ( -50 vs. $+50 \%$ cloud cover), full-moon versus new-moon, low versus high wind speeds (0-32 vs. 32-56 km/hr), and warm versus cold temperatures $\left(+18\right.$ to -15 vs. -15 to $\left.-23^{\circ} \mathrm{C}\right)$. No significant relationships were found for the same comparisons in proportion of time devoted to resting.

Key Words: Odocoileus hemionus hemionus, winter habitat preference, daily activity patterns, radio-telemetry, behavior, home range

Habitat for mule deer (Odocoileus hemionus hemionus) along much of the Front Range of Colorado is diminishing due to expansion of nearby cities and demand for diversion of habitat areas to human uses. Because decision on land use may have great impact on mule deer habitat, better understanding of deer-habitat relationships along the Front Range is needed to maintain the deer population.

The tendency of mule deer and Columbian blacktailed deer $(O$. $h$. columbianus) to exhibit preference for certain habitat components within existing vegetation complexes has been described (Mackie 1970, Telfer 1978, Barrett 1982, Hanley 1984, Harestad 1985, Carson and Peek 1987). The purpose of this study is to

\footnotetext{
Authors are wildlife researcher, Colorado Division of Wildlife, 317 W. Prospect, Fort Collins 80526; professor, Statistics Department, Colorado State University, Fort Collins 80523; and wildlife program specialist, Colorado Division of Wildlife, 6060 Broadway, Denver 80216.

Research was funded by Federal Aid in Fish and Wildlife Restoration, Colorado Project FW26P. We thank S. McHugh, B. Parmenter, K. Risenhoover, L. Roberts, and D. Schaad for field assistance; C. Smith, $O$. Landahl, P. Strong, and N. Ting for computer work; $L$. Lovett for assistance in manuscript preparation, and $R$. Morris, $C$. Bergman, and B. Mayer of Colorado Division of Parks and Recreation for their cooperation in making the study area available. We also thank $D$. Radtke and $K$. Davis of the U.S. Fish and Wildlife Service Western Energy and Land Use Team for use of computer facilities; and A. Anderson, N.T. Hobbs, and W. Hoffman for manuscript review.

Manuscript accepted 29 June 1988.
}

measure the relative degree of preference deer exhibit, during winter, for certain major Colorado Front Range vegetation types for feeding and resting; to determine if the degree of preference varies by time of day; and to determine if other environmental factors influence deer activity patterns. Such information will be useful to range and wildlife personnel concerned with habitat evaluation and improvement or with mitigation of habitat losses.

In the study we examined 4 general hypotheses. (1) The proportion of time deer spend feeding and resting varies among 4 daily periods: sunrise, daytime, sunset, and night. (2) Deer alter their activity patterns in response to environmental influences; specifically, snow depth, temperature, wind velocity, cloud cover, and moon phase. (3) Deer select specific vegetation types for feeding and resting, and selectivity varies among 4 daily periods: sunrise, daytime, sunset, and night. (4) Deer select vegetation ecotones for feeding and resting. Within these 4 general hypotheses, we examined hypotheses for given comparisons among activity, daily period, or environmental factor combinations.

\section{Study Area}

The study area, approximately $14.5 \mathrm{~km}^{2}$, is about $5 \mathrm{~km}$ west of Fort Collins, Colorado, and lies mainly within the boundaries of Lory State Park. It is bounded on the east by Horsetooth Reservoir, on the west by the ridge extending north from Horsetooth Mountain, and on the south by the southern park boundary. Elevations range from $1,646 \mathrm{~m}$ at the reservoir shoreline to $2,138 \mathrm{~m}$ on Horsetooth Mountain over a linear distance of about $2.5 \mathrm{~km}$. Steep, rugged, uplifted hogbacks capped by vertical rock outcrops occur along the western shore of the reservoir. These are covered by dense stands of true mountain mahogany (Cercocarpus montanus) interspersed with grassland (Bromus secalinus and Stipa spp.) openings and small patches of ponderosa pine (Pinus ponderosa). West of the hogback lies an open valley about $0.6 \mathrm{~km}$ wide running north and south the length of the area. It is mainly grassland with very dense thickets of sumac (Rhus aromatica), hawthorn (Crataegus erythropoda), chokecherry (Prunus virginiana), and wild plum (Prunus americana) along draws. Horsetooth Mountain is an area of rugged, mountainous terrain with numerous rock outcrops, ridges, and canyons. Lower portions and some south-facing slopes in higher sections support dense mountain mahogany with patches of ponderosa pine and grass. Higher portions are covered by extensive stands of ponderosa pine with varying canopy coverages interspersed with Douglas fir (Pseudotsuga menziesii), mountain meadows dominated by Poa spp. and Thermopsis divaricarpa, and small grassland parks.

\section{Materials and Methods}

Radio-telemetry involving a 2-wavelength, precision-null antenna system was used to measure deer habitat selection and activity patterns. Immediately preceding the study, performance of the precision-null antenna system was evaluated on the study area. A description of the system, its directional accuracy on this study area, and procedures used in locating transmitters with it are described by Kufeld et al. (1987).

Each radio collar used in the study (radio collars were manufactured by Telonics, Inc., of Mesa, Ariz. ${ }^{1}$ ) was equipped with an

${ }^{1}$ Reference to this trade name does not imply endorsement by the State of Colorado. 
activity switch which permitted monitoring whether a deer was in head up or head down position by instantly changing pulse rate when the head moved above or below horizontal. Signals were transmitted to a receiver-digital processor and recorded on a Rustrac', model 388, dual channel, 12-V strip chart recorder. One side of the chart indicated head position, while the other side simultaneously recorded signal strength in decibels, indicating whether the deer was active or inactive. The chart was calibrated in 2minute intervals for time determination.

A preliminary evaluation was also conducted to determine how to accurately recognize deer activities from patterns plotted on strip charts. A tame deer ( 4 different individuals were used) wearing a radio collar was allowed to roam freely on the study area. Its movements were recorded using telemetry equipment and a strip chart recorder carried by 2 observers who accompanied the deer. Three activity categories ("feeding, resting, and other") were recognized. We define "feeding" as actively taking in food (either head up or head down), "resting" as immobile, and "other" as everything a deer does when not actively feeding or resting. The "other" category included walking, running, intermittent feeding, and standing. A deer is immobile when standing, but standing could be differentiated from "resting" because resting deer were usually immobile for more than 5 minutes. Each time a deer changed its activity, a label was placed on the chart to identify the activity. A 32-hr record of charted, known activities was assembled. Both observers watched the deer and studied the charts until they felt they had attained proficiency in recognizing activity patterns by reading charts.

Tests were then conducted to determine the degree of accuracy in recognizing activity patterns on strip charts attained by the observer who would be the chart reader during the course of the study (Observer A). One observer (Observer B) accompanied the instrumented deer and labelled feeding, resting, and other activities on his chart. Observer A simultaneously recorded the deer's activity using a duplicate set of telemetry equipment and chart recorder, but from a position where he could not see the deer or Observer B.

Table 1. Proportion of time deer devoted to feeding, resting, and other activities during 4 daily periods at Lory State Park.1

\begin{tabular}{|c|c|c|c|c|c|c|c|}
\hline \multirow[b]{3}{*}{ Daily period } & \multicolumn{6}{|c|}{$\%$ of time devoted to activity } & \multirow{3}{*}{$\begin{array}{l}\text { Total deer } \\
\text { locations }\end{array}$} \\
\hline & \multicolumn{2}{|c|}{ Feeding } & \multicolumn{2}{|c|}{ Resting } & \multicolumn{2}{|c|}{ Other } & \\
\hline & Mean & CV & Mean & CV & Mean & CV & \\
\hline $\begin{array}{l}\text { Sunrise } \\
\text { Daytime } \\
\text { Sunset } \\
\text { Night }\end{array}$ & $\begin{array}{l}36.94 \\
23.01 \\
39.48 \\
39.98\end{array}$ & $\begin{array}{l}6.74 \% \\
9.86 \\
7.24 \\
6.64\end{array}$ & $\begin{array}{l}33.82 \\
39.63 \\
29.36 \\
38.78\end{array}$ & $\begin{array}{l}5.85 \% \\
5.30 \\
6.71 \\
5.39\end{array}$ & $\begin{array}{l}29.25 \\
37.36 \\
31.16 \\
22.23\end{array}$ & $\begin{array}{c}10.29 \% \\
6.53 \\
8.02 \\
10.80\end{array}$ & $\begin{array}{l}1,043 \\
1,037 \\
1,034 \\
1,041\end{array}$ \\
\hline \multicolumn{8}{|c|}{ Calculated significance of paired- $t$ tests ${ }^{2}$} \\
\hline $\begin{array}{l}\text { Sunrise vs. daytime } \\
\text { Sunrise vs. sunset } \\
\text { Sunrise vs. night } \\
\text { Daytime vs. sunset } \\
\text { Daytime vs. night } \\
\text { Sunset vs. night }\end{array}$ & & $\begin{array}{l}0.00^{*} \\
0.30 \\
0.42 \\
0.00^{*} \\
0.00^{*} \\
0.86\end{array}$ & & $\begin{array}{l}0.01^{*} \\
0.07 \\
0.04^{*} \\
0.00^{*} \\
0.75 \\
0.00^{*}\end{array}$ & & $\begin{array}{l}0.00^{*} \\
0.41 \\
0.00^{*} \\
0.01^{*} \\
0.00^{*} \\
0.00^{*}\end{array}$ & \\
\hline
\end{tabular}

'Based on 22 deer. All 22 were monitored for 1 winter; 20 were monitored for 2 winters and 13 were monitored for 3 winters.

${ }^{2}$ Comparison of means.

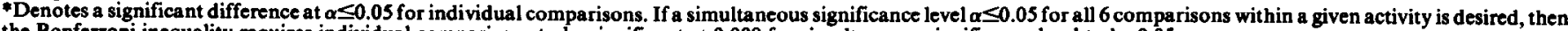
the Bonferroni inequality requires individual comparisons to be significant at 0.008 for simultaneous significance level to be 0.05 .

Table 2. Effects of various environmental factors on daily activity patterns of deer.1

\begin{tabular}{|c|c|c|c|c|c|c|}
\hline \multirow[b]{2}{*}{ Environmental factor } & \multirow[b]{2}{*}{ Criteria } & \multicolumn{4}{|c|}{ Percent of time devoted to activity } & \multirow{2}{*}{$\begin{array}{l}\text { No. of deer } \\
\text { in test }\end{array}$} \\
\hline & & Feeding & CV & Resting & CV & \\
\hline \multirow[t]{2}{*}{ Snow depth } & $\begin{array}{l}\text { over } 36 \mathrm{~cm} \\
\text { under } 36 \mathrm{~cm}\end{array}$ & $\begin{array}{l}25.4 \\
33.9 \\
\end{array}$ & $\begin{array}{c}18.1 \% \\
7.2\end{array}$ & $\begin{array}{l}53.4 \\
34.5 \\
\end{array}$ & $\begin{array}{l}6.3 \% \\
4.0\end{array}$ & \\
\hline & Calculated significance & $0.03^{*}$ & & $0.00^{*}$ & & 16 \\
\hline \multirow[t]{2}{*}{ Temperature } & $\begin{array}{l}\text { above }-15^{\circ} \mathrm{C} \\
\text { below }-15^{\circ} \mathrm{C}\end{array}$ & $\begin{array}{l}34.6 \\
32.7 \\
\end{array}$ & $\begin{array}{r}6.5 \\
15.3\end{array}$ & $\begin{array}{l}32.0 \\
35.7 \\
\end{array}$ & $\begin{array}{r}4.9 \\
11.2\end{array}$ & \\
\hline & Calculated significance & 0.36 & & 0.16 & & 12 \\
\hline \multirow[t]{2}{*}{ Wind } & $\begin{array}{l}\text { over } 32 \mathrm{~km} / \mathrm{hr} \\
\text { under } 32 \mathrm{~km} / \mathrm{hr}\end{array}$ & $\begin{array}{l}33.1 \\
32.6 \\
\end{array}$ & $\begin{array}{r}14.5 \\
8.9\end{array}$ & $\begin{array}{r}37.7 \\
\mathbf{3 2 . 4} \\
\end{array}$ & $\begin{array}{r}13.6 \\
4.9\end{array}$ & \\
\hline & Calculated significance & 0.92 & & 0.33 & & 12 \\
\hline \multirow[t]{2}{*}{ Moon phase } & $\begin{array}{l}\text { full moon } \\
\text { new moon }\end{array}$ & $\begin{array}{l}40.1 \\
39.9 \\
\end{array}$ & $\begin{array}{l}9.7 \\
8.1\end{array}$ & $\begin{array}{l}41.7 \\
37.5 \\
\end{array}$ & $\begin{array}{l}9.8 \\
7.8\end{array}$ & \\
\hline & Calculated significance & 0.96 & & 0.28 & & 16 \\
\hline \multirow[t]{2}{*}{ Cloud cover } & $\begin{array}{l}\text { over } 50 \% \\
\text { under } 50 \%\end{array}$ & $\begin{array}{l}38.0 \\
40.4 \\
\end{array}$ & $\begin{array}{l}11.4 \\
16.8\end{array}$ & $\begin{array}{l}41.1 \\
26.1 \\
\end{array}$ & $\begin{array}{l}13.9 \\
13.5\end{array}$ & \\
\hline & Calculated significance & 0.71 & & 0.08 & & 10 \\
\hline
\end{tabular}

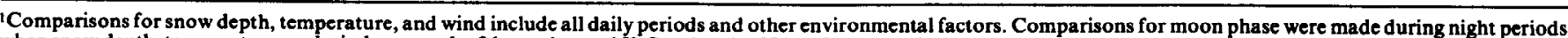

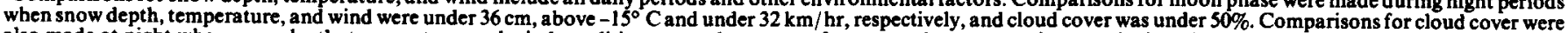
also made at night when snow depth, temperature, and wind conditions were the same as for moon phase comparisons and when the moon was full.

-Denotes a significant differences at $\alpha \leq 0.05$. 
Observer $A$ then reviewed his chart and labelled patterns he believed indicated feeding, resting, or other activity. The number of minutes in time segments Observer A assigned to a given activity was compared with the actual time devoted to those activities as recorded on Observer B's chart. During 2 tests which covered a total of 2,239 minutes of recorded deer activity, Observer A correctly classified 95 and $98 \%$ of minutes deer devoted to feeding, 99 and $90 \%$ of minutes devoted to resting, and 95 and $95 \%$ of minutes devoted to other activities. The key to identification of feeding, resting, and other activities lay in recognizing chart patterns produced over varying lengths of time. A 10 -minute period of charting was deemed adequate to establish a deer's primary mode of activity at a particular time. Gillingham and Bunnell (1985) reported less success in recognizing deer activity patterns using tip-switch collars.
The study was based on 22 adult female deer captured and fitted with 2 numbered ear tags and radio collars. Ten of these deer were instrumented between 19 January and 14 October 1982, and 12 instrumented between 31 January and 3 February 1983. Beginning in 1982, locations of does were monitored extensively from midNovember through March for 3 winters by triangulation using 2, 2-wavelength precision-null antenna systems mounted on pickup campers. Mortality during the 3-yr duration of the study reduced the number of instrumented deer available for monitoring from 22 during year 1 to 20 and 13 during years 2 and 3 , respectively. A total of 4,365 locations was recorded.

Triangulation to locate instrumented deer was accomplished from 2 sites (receiver points) on the east side of Horsetooth Reservoir. Preliminary tests (Kufeld et al. 1987) indicated the 2wavelength precision-null antenna system permitted detecting

Table 3. Preference or lack of preference for vegetation types as foeding and resting areas during 4 daily periods based on 22 deer.

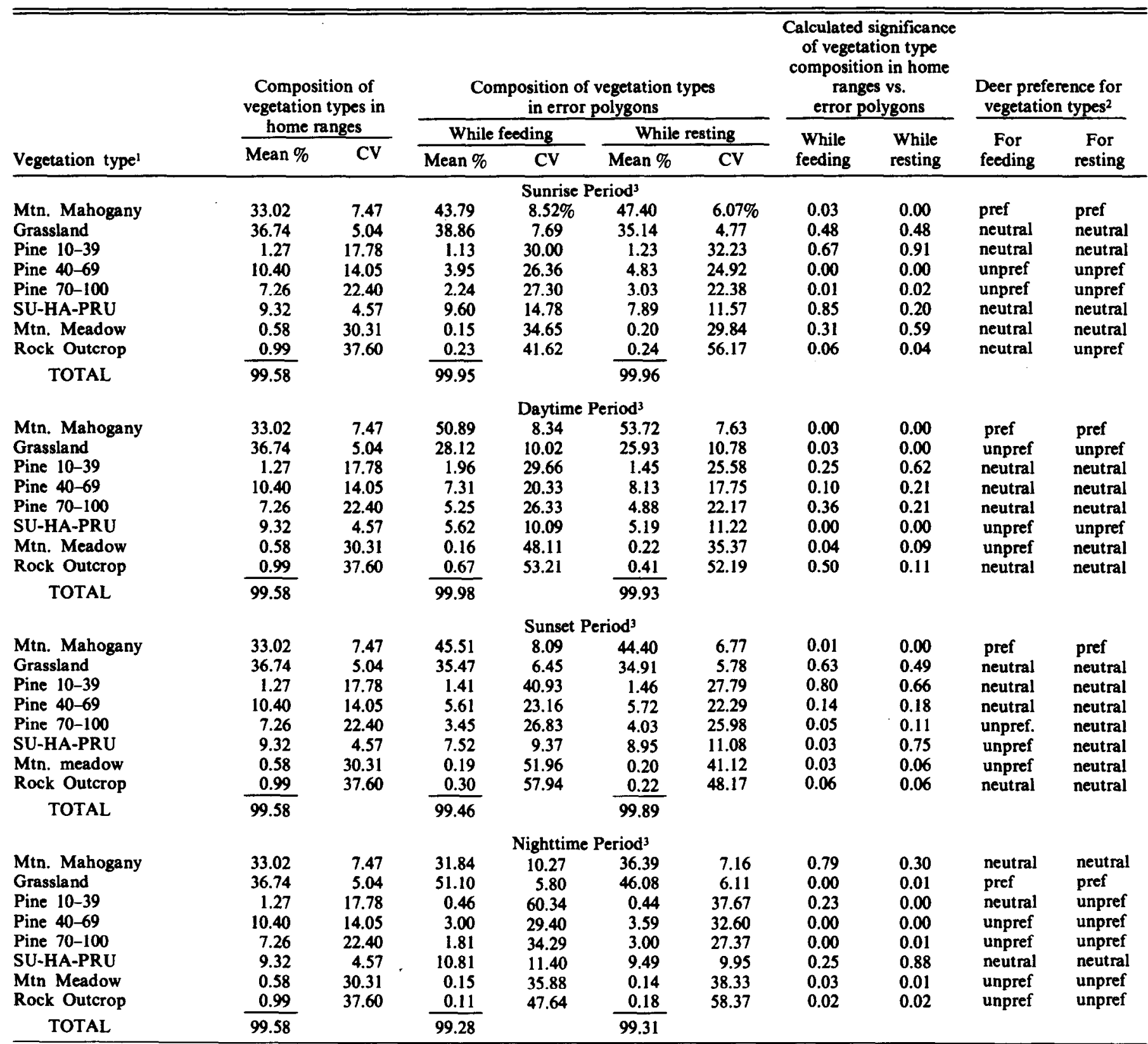

IPine 10-39, 40-69 and 70-100 represent percent canopy coverage, SU-HA-PRU is the sumac-hawthorn-Prumus type.

2Mean percent composition of a given vegetation type in error polygons, while deer were engaged in a particular activity, was significantly higher $(P \leq 0.05)$ than mean percent composition of that vegetation type in minimum convex polygon home ranges if that type was preferred by deer for that activity, not significantly different $(P>0.05)$ if preference for it was neutral, and significantly lower $(P \leq 0.05)$ if it was unpreferred.

${ }^{3} \mathrm{~A}$ sampling period lasted $6 \mathrm{hrs}$ and extended from $3 \mathrm{hrs}$ before to $3 \mathrm{hrs}$ after sunrise, mid-day, sunset, midnight. 
directionality of radio signals on the study area with sufficient accuracy to allow triangulation from only 2 sites. The relatively small sizes of deer home ranges we estimated using this antenna system and procedures described by Kufeld et al. (1987) reflects a high degree of telemetry accuracy. If deer home ranges were, in actuality, relatively small but telemetry accuracy was poor, our estimates of deer home range size would have been expected to be much larger. Antenna attitude was positioned and calibrated at the start of each monitoring session by orienting the antenna toward a fixed beacon transmitter located atop Horsetooth Mountain. A compass rose on the mast of each antenna was then set to coincide with the surveyed bearing from its receiver point to the beacon. Operators communicated via 2-way radios to facilitate obtaining simultaneous directional bearings on each instrumented deer.

Instrumented deer were located during each of 4 daily sampling periods; sunrise, daytime, sunset, and night. A sampling period lasted $6 \mathrm{hrs}$ and extended from $3 \mathrm{hrs}$ before to $3 \mathrm{hrs}$ after sunrise, mid-day, sunset, and midnight. Since there were more hours of darkness and fewer of light during winter, there was some overlap between the sunrise and daytime period and daytime and sunset period. Mean overlap was $62,81,72,39$, and 2 minutes, respectively, during November December, January, February, and March. There was no overlap between sunset and night or night and sunrise periods. We assumed that if differences occurred between periods in deer activity modes, they would be most pronounced at times near period mid-points (i.e., the times closest to sunrise vs. times closest to mid-day), and that deer activity modes during 2 adjacent periods near the end of one period and beginning of another would be similar. Thus, monitoring of deer activity during proportionately short overlap periods was not expected to adversely affect inter-period activity comparisons, and any detrimental effects that might be realized would be outweighed by consistency provided by maintaining 4 periods of equal ( $6 \mathrm{hrs})$ length. Only one period was scheduled for deer monitoring per 24 hrs. Twelve sampling periods were scheduled per month $(3$ of each kind) except that 8 periods were scheduled during December ( 2 of each kind). Thus, during the 3 winters, there were 168 sampling periods including 42 of each kind. Each deer was located 1 to 3 times during a sampling period. At least 1 location of each deer currently in the study was obtained during $98 \%$ of 168 scheduled 6-hr monitoring periods. Variation in number of locations per deer was essentially associated with the number of deer currently in the study and not with their activity or location.

At the beginning of each monitoring period, the first deer to be located was selected by obtaining a random starting point on an ordered list of deer identifications and then proceeding down the list from the starting point. Immediately after a deer was located, its activity pattern was charted for 10 minutes on a strip chart recorder. Activity patterns were categorized according to feeding, resting, and other, based on the activity which occupied most of the deer's time during the 10 minutes.

A 1:14,049 scale, high resolution, color infrared aerial photo taken by NASA from a U-2 plane at an altitude of $21,336 \mathrm{~m}$ formed the basis for analysis of telemetry data. Distances and angles on this photo were compared with surveyed distances and angles on the ground. There was no apparent photo distortion. The study area was divided into 9 vegetation types, and boundaries of each type were digitized (Gilmer et al. 1973) so they could be regenerated in a map form by computer. A minimum size of 0.4 ha was established for considering an area as a distinct type. The 9 vegetation types were: 3 canopy coverages of ponderosa pine ( 10 to 39,40 to 69 , and 70 to $100 \%$ ), grassland, mountain mahogany, sumachawthorn-Prunus (SU-HA-PRU), mountain meadow, agricultural (only 1 small alfalfa field) and rock outcrop. Rock outcrop was considered a distinct type because areas of exposed rock with very sparse growths of ponderosa pine exceeding 0.4 ha were encountered.

Triangulation data were computerized and error polygons which one could be $90 \%$ confident that at least $81 \%$ of the individ- ual polygons contained the actual deer location were generated. Rationale and methodology for delineation of error polygons using nonparametric tolerance limits are described by Kufeld et al. (1987). Areas and percent composition of each vegetation type within error polygons were computed using various programs with the SAGIS system created by the U.S. Fish and Wildlife Service Western Energy and Land Use Team. Habitat usage was based on percent composition of each vegetation type occurring in error polygons as described by Kufeld et al. (1987).

Deer preference for habitat types was determined from paired observations of mean percent composition of a given vegetation type within the minimum convex polygon home range (Jennrich and Turner 1969, Southwood 1966) with mean percent composition of that vegetation type in telemetry error polygons for each instrumented deer. Habitat preference comparisons were made for various activities by paired- $t$ test and results labelled in the following manner. If percent composition of vegetation type $A$ in error polygons, while deer were feeding, was not significantly different (calculated $P>0.05$ ) from percent composition within their corresponding home ranges, preference for type $A$ for feeding is labelled as neutral. If mean percent composition of type $A$ in error polygons significantly exceeded (calculated $P \leq 0.05$ ) corresponding mean home range composition, preference for type $A$ is labelled as preferred. This test only examines whether averaged over deer there is a habitat preference and not whether an individual deer has a preference. Type $A$ is labelled as unpreferred if percent composition of type $A$ in error polygons is significantly less (calculated $P \leq 0.05$ ) than corresponding home range composition.

To measure possible affinity of deer to ecotones, mean distances from deer-selected locations to the edge of the nearest adjacent vegetation type were compared with mean distances for locations plotted at random. One-hundred locations were plotted randomly within the minimum convex polygon home range of each instrumented deer for comparison with deer-selected locations. We labelled preference for an ecotone as neutral if there was no difference $(P>0.05)$ between mean deer selected and randomly selected distances. If a difference was found $(P \leq 0.05)$ and mean deer selected distances were less than randomly selected distances, (a ratio of $\langle 1.0$ ) the ecotone is labelled as preferred. The ecotone is labelled as unpreferred if a difference was found (calculated $P \leq 0.05$ ) and mean deer selected distances were greater than mean randomly selected distances (a ratio of $>1.0$ ). Preliminary telemetry accuracy tests (Kufeld et al. 1987) indicated that no consistent bias should be present in estimated deer locations compared with actual deer locations. Thus, the effect on statistical tests due to using estimated locations rather than actual locations is to reduce power of the tests; yet many significant differences were still detected. Only 3 vegetation types, grassland, mountain mahogany, and SU-HA-PRU, were used for ecotone comparisons because sample size for them was adequate, but inadequate for other vegetation types. Comparisons were made without regard for activity.

For statistical analysis, deer were viewed as the basic experimental unit. Thus, standard errors were based on differences among individual deer means. For each observation, the percentage composition of each vegetation type in the constructed error polygon and deer activity were recorded. Sample means of observations for each vegetation type for each deer within 36 categories ( 3 years by 4 periods by activities) were calculated for those deer which were present all 3 years. Analysis of variance techniques for these repeated measures data were used to test for year effects (main effects and interactions). Since few significant results were found among years for the numerous tests made, sample means for 12 period by activity categories were calculated for each vegetation type for each of 22 deer with pooled data for all $3 \mathrm{yrs}$. In addition, the proportion of observations within activity types were calculated for each deer by feeding, resting, and other activity periods.

Paired- $t$ tests were used to test for differences between periods in proportion of time spent feeding for each of the 6 pairs of periods 
possible, given 4 periods. Control of the error rate for these comparisons among periods was maintained by use of Bonferroni inequality (Sokal and Rohlf 1981). Similar comparison among periods were made for resting and other activities. This same set of tests between pairs of periods using paired- $t$ tests was made for the percentage composition of a given vegetation type within error polygon data for a given activity.

Percent composition of a given vegetation type within each deer's home range was also subtracted from the corresponding vegetation sample mean for each of the 12 periods by activity categories. These differences were then used in individual $t$ tests for each vegetation type for a given period and activity to test equality of the mean percentage composition of a given vegetation type within error polygons to the corresponding home range percentage figure. These last tests form the basis for determination of preference. Difference between mean distance of locations, within a given vegetation type, selected by each deer and randomly selected locations within that deer's home range, were used in $t$ tests to evaluate uniform utilization of area within a given vegetation type.

Several environmental factors were measured on the study area during each monitoring session. Snow depths were measured at 6 stations representing a north- and south-facing slope at low, middle, and high elevations within the study area. Temperature, wind velocity, and percent cloud cover were recorded at one of the triangulation points at the beginning, during, and end of each monitoring session. Moon phase was also recorded. Paired- $t$ tests were used to test for differences in percent time feeding (and/or resting) on monitoring days when an environmental factor of interest was above a specified level with percent time spent feeding (and/or resting) on days when the environmental factor was below that level. Because of mortality of some instrumented deer during the study, some deer had inadequate sample sizes to measure each level of an environmental factor. Only deer with adequate sample sizes for each level of an environmental factor were used in these analyses. Inadequate sample sizes were encountered when more than 2 levels of an environmental factor were used. (In all statistical tests, differences are stated to exist only if they were found significant at $P \leq 0.05$ ).

\section{Results and Discussion}

\section{Daily Activity Patterns and Environmental Influences}

Proportions of time devoted to feeding (Table 1) are somewhat conservative and proportions of time devoted to "other" activities are somewhat liberal because a deer was considered to be feeding when its main activity mode during a 10 -minute period was ingesting food. Intermittent feeding while the main activity mode was walking, searching for food, ruminating while standing, etc., was included in the "other" activities category. Differences in proportion of time female deer spent in given activities during specified periods (general hypothesis number 1) were found in some comparisons (Table 1). They fed most during sunset, night, and sunrise periods and least during the day. Feeding occupied similar proportions of an average deer's time during sunset, night, and sunrise periods. Deer rested most during daytime and night periods.

Precipitation amounts, temperatures, and wind velocities we encountered during 3 winters of monitoring deer were within normal range for the area. According to long-term U.S. Weather Bureau records for Fort Collins, November through March mean precipitation during the 3 winters departed from normal by only $-4.8 \mathrm{~cm},-4.8 \mathrm{~cm}$, and $+0.3 \mathrm{~cm}$, respectively. Winds also remained within normal ranges for the area.

Deer altered their activity patterns in response to some environmental influences (Table 2) (general hypothesis number 2). Observed increased resting and decreased feeding activity by deer during periods of deep snow $(>36 \mathrm{~cm}$ ) (Table 2) was probably for purposes of energy conservation. Energy expenditures for locomotion in snow have been shown to increase curvilinearly as a function of snow depth and density, and net energetic cost of travel to deer increases greatly in snow depths exceeding $25 \mathrm{~cm}$ (Parker et al. 1984). Loveless (1967) and Gilbert et al. (1970) reported that snow depths of 46 and $61 \mathrm{~cm}$, respectively, essentially preclude use of an area by mule deer. In our study when snow depths receded below $36 \mathrm{~cm}$, deer resumed feeding and resting in the same proportions as before the snowfall occurred. Study deer did not appear to be stressed by excessive snow. November-March precipitation during the 3 winters was near normal, and periods when snow depth exceeded $36 \mathrm{~cm}$ did not last more than a week at a time. No outward signs of weight loss or poor physical condition were observed in deer on the area at the end of any winter.

Air temperatures and wind velocities encountered during 3 winters of monitoring deer did not appear to influence the proportion of time deer fed or rested (Table 2). Our lowest recorded air temperature $\left(-23^{\circ} \mathrm{C}\right)$ is below the $-20^{\circ} \mathrm{C}$ operative temperature Parker and Robbins (1984) found to be the lower threshold for thermally critical environment for mule deer during winter. The operative temperature is that temperature actually experienced by the animal, and it can be derived from different environmental variables (Parker and Robbins 1984). Since the minimum air temperature occurred for only a few hours and since the operative temperature for individual deer may have been higher during that time because deer can take advantage of microclimates (Loveless 1967), operative temperatures likely remained above thermally critical levels during the study. Generally, low temperatures and high winds did not occur simultaneously, so the effect of the lowest temperatures on deer was not compounded by wind chill. We surmise that deer along foothills of the northern Front Range are adapted to temperatures and wind velocities that fall within the normal range for winter, and do not alter their feeding and resting patterns because of them. Lower temperatures and higher winds than we encountered (those that would exceed normal ranges for the area) or low temperature-high wind conditions may influence feeding and resting behavior, however.

There was no difference between clear, full-moon nights and cloudy, full-moon nights or between clear, full-moon nights and clear, new-moon nights in proportion of time deer spent feeding or resting (Table 2). This finding is contrary to the popular belief held by some hunters that deer hunting is more difficult when it is clear and the moon is full because deer feed at night. The instrumented deer spent a large proportion of their time feeding at night regardless of cloud cover or moon phase.

\section{Habitat Selection}

It should be clear that expression of preference (unpreferred, preferred, or neutral) by deer for a given vegetation type is only made conditional on the choices available in the existing habitat complex. Deer used unpreferred types, but less than preferred or neutral types, and there were fewer locations $(P \leq 0.05)$ in unpreferred types than if deer locations within home ranges were randomly selected. If those particular vegetation types for which deer showed preference had been absent from the study area, then neutral types may have become the preferred types and unpreferred types may have been elevated by deer to neutral status.

Minimum convex polygon home ranges, constructed from all locations for each deer, averaged 217 ha \pm 22 ha $(\bar{x} \pm 95 \%$ confidence limit) and ranged from 117 to 323 ha. Yearly minimum convex polygon home ranges for individual deer overlapped extensively. Home ranges were, thus, quite small and fixed over time considering the mobility of which a deer is capable.

Sizes of error polygons (in which one could be $90 \%$ confident that at least $81 \%$ of the individual polygons contained the actual deer location) generated during the study and used for habitat preference determination (as described under "Methods") were distributed as follows: $20.3 \%-0.1$ to $2 \mathrm{ha} ; 28.5 \%-2.1$ to $4 \mathrm{ha} ; 17 \%$ -4.1 to $6 \mathrm{ha} ; 12.5 \%-6.1$ to $8 \mathrm{ha} ; 10.3 \%-8.1$ to $10 \mathrm{ha} ; 3.0 \%-10.1$ to 12 ha; $3.3 \%-12.1$ to 14 ha; $5.1 \%>14$ ha.

Deer selected specific vegetation types for feeding and resting and selectivity varied among 4 daily periods (general hypothesis number 3 ). The most heavily used vegetation types for feeding and 
resting were the mountain mahogany and grassland types. These were also the most common types in terms of mean percent of area within home ranges (Table 3 ).

\section{Composition of Cover in Home Ranges}

Vegetation types on the study area were categorized according to "cover" types and "noncover" types based on how instrumented deer related to them during the daytime period when, because of high light conditions, deer must rely primarily on vegetation for concealment and security. Vegetation types that deer preferred or showed neutral preference for feeding or resting during the daytime period (Table 3) apparently offer adequate security for deer so they were designated as cover types. Those considered cover types are mountain mahogany, SU-HA-PRU, pine 10-39, pine 40-69, pine 70-100, and rock outcrop. The SU-HA-PRU type was unpreferred by deer for feeding and resting during daytime, but is included as a cover type because it does provide excellent concealment, and because deer preferred the grassland-SU-HA-PRU ecotone when they were in the grassland type during the daytime period. The grassland and mountain meadow types were considered noncover types because they were unpreferred by deer for feeding and resting during the daytime period. Thus, those types apparently do not offer adequate security for deer during daylight hours.

Our definition of cover did not consider insulating qualities which deer might seek for protection from heat or cold. Freddy (1985) found the absence of thermal cover did not appear to reduce potential for deer to survive winter. Since winter temperatures on his study area (Kremmling, Colo.) averaged far lower than ours, we assume that our instrumented deer used cover primarily for security reasons. Sixty-two percent of the area within home ranges of 22 instrumented deer consisted of what we call cover types and the remaining $38 \%$ consisted of noncover types (Table 3 ).

\section{Preference for Vegetation Types}

A range area may contain a variety of vegetation types which individually contain some, or perhaps all, of the habitat needs of deer. If an individual type is capable of satisfying all of a deer's requirements, habitat diversity may not be necessary. Where types exist that can provide only some of a deer's requirements or can provide them only during specific time periods, it becomes necessary that a complex of types, which together can satisfy all of a deer's needs, be present within the home range of each deer. For example, we found composition of what we defined as cover and noncover types within deer home ranges to be $62 \%$ and $38 \%$, respectively, but a more productive ratio might be $100 \%$ cover and $0 \%$ noncover as long as the cover types alsu satisfied all of the deer's needs for feeding.

Observed preferences or lack of preference by our instrumented deer for specific vegetation types on the study area appear related to foliage and its use by deer for feeding and cover. Loveless (1967), working on nearby deer ranges and in similar habitats, also observed that deer were not randomly dispersed over the range but concentrated in habitats which provided food and cover.

Contrary to the hypothesis of Hanley (1982) that deer should select dicot-dominated habitats for feeding, we found that grassland was a preferred feeding type for deer (Table 3 ). This can be

Table 4. Comparison of distances from deer selected versus randomly selected locations to the edge of the nearest adjacent vegetation type.

\begin{tabular}{|c|c|c|c|c|c|c|c|c|}
\hline \multicolumn{2}{|c|}{ Vegetation typel } & \multirow{3}{*}{$\begin{array}{l}\text { No. of instru- } \\
\text { mented deer } \\
\text { averaged }\end{array}$} & \multicolumn{4}{|c|}{$\begin{array}{c}\text { Distance }(m) \text { from location to edge of } \\
\text { nearest adjacent vegetation type }\end{array}$} & \multirow{3}{*}{$\begin{array}{c}\text { Ratio of } \\
\text { deer selected } \\
\text { to random } \\
\text { location } \\
\text { distances }^{3}\end{array}$} & \multirow{3}{*}{$\begin{array}{c}\text { Calculated } \\
\text { significance } \\
\text { deer } \\
\text { selected } \\
\text { vs. random } \\
\text { distance } \\
\end{array}$} \\
\hline Type containing & Adjacent type nearest to & & \multicolumn{2}{|c|}{ Deer selected location } & \multicolumn{2}{|c|}{ Random location ${ }^{2}$} & & \\
\hline location & location & & Mean & $\mathrm{CV}$ & Mean & CV & & \\
\hline $\begin{array}{l}\text { Grassland } \\
\text { Grassland } \\
\text { Mtn. mahogany } \\
\text { Mtn. mahogany } \\
\text { SU-HA-PRU } \\
\text { SU-HA-PRU }\end{array}$ & $\begin{array}{l}\text { Mtn. mahogany } \\
\text { SU-HA-PRU } \\
\text { Grassland } \\
\text { SU-HA-PRU } \\
\text { Grassland } \\
\text { Mtn. mahogany }\end{array}$ & $\begin{array}{l}22 \\
21 \\
22 \\
17 \\
17 \\
11\end{array}$ & $\begin{array}{r}\text { Sunrise } \\
22 \\
37 \\
57 \\
34 \\
18 \\
13\end{array}$ & $\begin{array}{l}9 \% \\
8 \\
10 \\
15 \\
19 \\
18\end{array}$ & $\begin{array}{l}30 \\
52 \\
42 \\
32 \\
15 \\
11\end{array}$ & $\begin{array}{l}6 \% \\
6 \\
7 \\
10 \\
8 \\
17\end{array}$ & $\begin{array}{l}0.72 \\
0.72 \\
1.37 \\
1.05 \\
1.23 \\
1.20\end{array}$ & $\begin{array}{l}0.00^{*} \\
0.00^{*} \\
0.01^{*} \\
0.72 \\
0.36 \\
0.53\end{array}$ \\
\hline $\begin{array}{l}\text { Grassland } \\
\text { Grassland } \\
\text { Mtn. mahogany } \\
\text { Mtn. mahogany } \\
\text { SU-HA-PRU } \\
\text { SU-HA-PRU }\end{array}$ & $\begin{array}{l}\text { Mtn. mahogany } \\
\text { SU-HA-PRu } \\
\text { Grassland } \\
\text { SU-HA-PRU } \\
\text { Grassland } \\
\text { Mtn. mahogany }\end{array}$ & $\begin{array}{l}20 \\
19 \\
22 \\
19 \\
11 \\
11\end{array}$ & $\begin{array}{c}\text { Daytime } \\
22 \\
40 \\
65 \\
30 \\
20 \\
13\end{array}$ & $\begin{array}{l}12 \\
16 \\
12 \\
14 \\
20 \\
18\end{array}$ & $\begin{array}{l}30 \\
51 \\
42 \\
35 \\
16 \\
14\end{array}$ & $\begin{array}{r}6 \\
7 \\
6 \\
12 \\
8 \\
15\end{array}$ & $\begin{array}{l}0.73 \\
0.78 \\
1.55 \\
0.86 \\
1.27 \\
0.91\end{array}$ & $\begin{array}{l}0.05^{*} \\
0.04^{*} \\
0.00^{*} \\
0.46 \\
0.32 \\
0.73\end{array}$ \\
\hline $\begin{array}{l}\text { Grassland } \\
\text { Grassland } \\
\text { Mtn. mahogany } \\
\text { Mtn. mahogany } \\
\text { SU-HA-PRU } \\
\text { SU-HA-PRU }\end{array}$ & $\begin{array}{l}\text { Mtn. mahogany } \\
\text { SU-HA-PRU } \\
\text { Grassland } \\
\text { SU-HA-PRU } \\
\text { Grassland } \\
\text { Mtn. mahogany }\end{array}$ & $\begin{array}{l}22 \\
22 \\
21 \\
19 \\
19 \\
10\end{array}$ & $\begin{array}{r}\text { Sunset } \\
21 \\
40 \\
57 \\
35 \\
15 \\
12\end{array}$ & $\begin{array}{l}10 \\
11 \\
10 \\
12 \\
12 \\
19\end{array}$ & $\begin{array}{l}30 \\
52 \\
43 \\
34 \\
15 \\
11\end{array}$ & $\begin{array}{r}6 \\
6 \\
6 \\
11 \\
12 \\
18\end{array}$ & $\begin{array}{l}0.71 \\
0.77 \\
1.34 \\
1.03 \\
1.02 \\
1.09\end{array}$ & $\begin{array}{l}0.00^{*} \\
0.02^{*} \\
0.01^{*} \\
0.87 \\
0.95 \\
0.75\end{array}$ \\
\hline $\begin{array}{l}\text { Grassland } \\
\text { Grassland } \\
\text { Mtn. mahogany } \\
\text { Mtn. mahogany } \\
\text { SU-HA-PRU } \\
\text { SU-HA-PRU }\end{array}$ & $\begin{array}{l}\text { Mtn. mahogany } \\
\text { SU-HA-PRU } \\
\text { Grassland } \\
\text { SU-HA-PRU } \\
\text { Grassland } \\
\text { Mtn. mahogany }\end{array}$ & $\begin{array}{l}22 \\
22 \\
21 \\
18 \\
21 \\
11\end{array}$ & $\begin{array}{c}\text { Night } \mathbf{F} \\
36 \\
49 \\
57 \\
37 \\
17 \\
12\end{array}$ & $\begin{array}{r}11 \\
7 \\
11 \\
19 \\
11 \\
19\end{array}$ & $\begin{array}{l}30 \\
52 \\
43 \\
35 \\
15 \\
10\end{array}$ & $\begin{array}{r}6 \\
6 \\
6 \\
13 \\
7 \\
19\end{array}$ & $\begin{array}{l}1.21 \\
0.95 \\
1.32 \\
1.04 \\
1.18 \\
1.18\end{array}$ & $\begin{array}{l}0.07 \\
0.44 \\
0.03 * \\
0.84 \\
0.27 \\
0.52\end{array}$ \\
\hline
\end{tabular}

ISU-HA-PRU is the sumac-hawthorn-Prunus type.

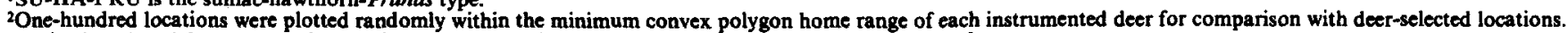

${ }^{3}$ Ratios less than 1.0 suggest preference for ecotones. Ratios greater than 1.0 suggest lack of preference for ecotones.

A sampling period lasted 6 hrs and extended from 3 hrs before to 3 hrs after sunrise, mid-day, sunset, midnight.

Denotes a significant difference at $\alpha \leq 0.05$. 
explained as follows: Immature grasses resemble dicots in their cell wall characteristics, with low levels of neutral detergent fiber and lignin, and consequently allow rapid excretion that is critical to deer digestion (Spalinger et al. 1986). Because temperatures are frequently mild on our study area, green grass could be found at least in small amounts throughout the winter. Others (Carpenter et al. 1979, and Spowart and Hobbs 1985) have reported high proportions of grass in winter diets of Colorado mule deer. According to Hobbs and Spowart (1984), grasses in a nearby grassland community were highly nutritious, containing from $6.3-8.1 \%$ crude protein and from $43-46 \%$ in vitro digestible dry matter during 2 consecutive winters. The grassland type is very open and without cover, and we surmise that deer use these areas only when concealed by darkness because grassland was preferred for feeding and resting at night, neutral for feeding and resting during sunrise and sunset periods, and unpreferred for both activities during daytime (Table 3). This is substantiated by the finding that deer in the grassland type preferred ecotones (general hypothesis number 4) with the mountain mahogany and SU-HA-PRU types, which offer cover and security during sunrise, daytime, and sunset; but at night deer apparently did not need the concealment offered by those ecotones when in the grassland type (Table 4). (Table 4 shows that lack of preference for the grassland-mountain mahogany ecotone at night was not significant at $P \leq 0.05$, but calculated $P$ was 0.07 ). Within the habitat complex examined, grassland appears to be a very important deer habitat component. However, because it is used mainly at night and lacks adequate cover needed by deer for daytime use, we extrapolate that to be considered suitable deer habitat, grassland should occupy less than $50 \%$ of a deer's home range area and occur in small patches. This recommendation follows since interior areas of large patches of grassland (more than $100 \mathrm{~m}$ from a cover type) received less use than did ecotonal areas. The cover-type patch should be of sufficient size and density to provide enough concealment that deer using it appear to feel secure.

Observed deer preference for the mountain mahogany type as a habitat for feeding (Table 3) is supported by Medin and Anderson (1979), who found that mountain mahogany comprised 25\% (by weight) of the botanical composition in 52 mule deer rumens collected year long from nearby deer ranges. Another factor that may have influenced preference for the mountain mahogany type for feeding is that it has an understory of the same grasses that occur in the grassland type. Observed deer preference for the mountain mahogany type for both feeding and resting (Table 3 ) is consistent with higher densities of fecal pellet groups in mountain mahogany than in coniferous habitat reported on nearby deer ranges by Anderson et al. (1972). The mountain mahogany type may supply both food and cover requirements for deer since they preferred it for feeding and resting during daylight hours (sunrise, daytime, and sunset periods) and did not gravitate toward ecotones with grassland or SU-HA-PRU types during any period when located in mountain mahogany (Table 4). Thus, even very large monotypes of mountain mahogany should be considered prime deer habitat.

The SU-HA-PRU type is very dense and should provide excellent concealment for deer. It occurs as long, narrow configurations of vegetation in draws surrounded by large patches of mountain mahogany and/or grassland. Deer preference for those adjacent types for feeding and resting may have contributed to the unpreferred status of the SU-HA-PRU type for feeding and resting during daytime and for feeding during sunset, and its neutral status during other periods (Table 3 ). Neutral preference for ecotones with mountain mahogany and grassland types during all periods while deer were in the SU-HA-PRU type (Table 4) may have been a result of the narrow pattern in which the SU-HA-PRU type occurs. If resting and escape cover needs of deer using the grassland type are satisfied by mountain mahogany or some other cover type, then existence of the SU-HA-PRU type in a deer habitat complex may not be necessary.
Preference by deer for the ponderosa pine types as a feeding habitat decreased as canopy cover increased (Table 3). This is consistent with a strong negative correlation between canopy coverage and understory herbage production reported by Metz (1974) in Colorado Front Range pine forests. On our study area the 10-39\% pine canopy coverage type has an understory of primarily mountain mahogany. The understory gives way to sparse stands of Vaccinium or no vegetation at all in the pine type with canopy coverage of 70-100\%. Deer apparently find adequate concealment in the ponderosa pine types for resting because they used all densities of the pine type for resting during daytime and sunset and used the pine 10-39\% canopy coverage type for resting during sunrise. Preference for pine for resting during those periods, however, was neutral (Table 3). Deer preferred the mountain mahogany type for resting during sunrise, daytime, and sunset. In the absence of the mountain mahogany and grassland types, the pine with $10-39 \%$ canopy coverage and a mountain mahogany understory would likely become the main feeding type and its importance for resting would likely also increase. Thus, large monotypes of pine 10-39\% could be considered good deer habitat. Because the $40-69 \%$ and $70-100 \%$ canopy coverage pine types provide only resting cover, however, optimum composition of dense pine in a deer range depends on what vegetation types are available nearby for feeding. If adjacent feeding types are primarily open gras $\$$ land, and the $40-69 \%$ and $70-100 \%$ canopy coverage pine types provide the only available cover offering security for resting, then these dense pine types should occupy perhaps as much as $50 \%$ of the range area. If, however, other higher quality types such as mountain mahogany or 10-39\% canopy coverage pine with a mountain mahogany understory are available to provide both feeding and resting cover, then the composition of $40-69 \%$ and $70-100 \%$ canopy coverage pine types can be proportionately less. Thinning and patch cutting in ponderosa pine and mixed conifer stands have resulted in substantial increases in grass and forb production and subsequent deer use (Clary and Ffolliott 1966, Patton 1974, Patton 1976). Thus, where large, dense pine monotypes exist, deer habitat could be improved by converting pine in excess of that needed for security cover to openings where forage species could become established through natural regeneration or reseeding. If created openings are converted to grass and forbs, those openings should not exceed $200 \mathrm{~m}$ in width so no point in the opening is more than $100 \mathrm{~m}$ from cover, as was previously suggested for patch size in the grassland type.

In the vegetation complex on our study area mountain meadows were among the least utilized vegetation types by deer for both feeding and resting (Table 3 ). This may have been partly due to availability of more preferred types for both activities. Mountain meadows may be characterized by various kinds of plant species depending on elevation, precipitation, etc. In another situation where other, more preferred types are not readily available or where different plants occur in mountain meadows, the mountain meadow type may become of increased importance to deer (Patton and Judd 1970).

Neutral status of rock outcrop areas for feeding and resting during daytime suggests such areas provide adequate mid-day habitat for deer. Rock outcrop areas were unpreferred for both feeding and resting at night (Table 3 ). If, however, deer habitat needs during mid-day are satisfied by mountain mahogany or some other type, then existence of rock outcrop areas in a deer habitat complex may not be necessary.

\section{Conclusions}

We conclude: (1) Deer along the northern Colorado Front Range are adapted to temperatures and wind velocities that fall within the normal range for winter and do not alter their feeding and resting patterns because of them, but do adjust to periods of deep snow $(>36 \mathrm{~cm})$ by spending more of their time resting to conserve energy. (2) Deer select and concentrate in specific vegeta- 
tion types that satisfy their needs for food and security, and their degree of preference for specific habitats varies by periods of day and night. When using vegetation types where security cover was inadequate, deer distributed themselves near ecotones with habitats that offer cover and security.

We recommend that when evaluating deer habitat or preparing a habitat improvement or mitigation plan for deer range, consideration should be given to the juxtaposition, size, and relative contribution of each patch of existing vegetation in the habitat complex to the overall food and cover needs of deer in the area, together with ways to improve the complex.

\section{Literature Cited}

Anderson, A.E., and D.E. Medin., and D.C. Bowden. 1972. Mule deer numbers and shrub yield-utilization on winter range. J. Wildl. Manage. 36:571-578.

Barrett, R. 1982. Habitat preferences of feral hogs, deer and cattle on a Sierra foothill range. J. Range Manage. 35:342-346.

Carpenter, L.H., O.C. Wallmo, and R.B. Gill. 1979. Forage diversity and dietary selection by wintering mule deer. J. Range Manage. 32:226-229.

Carson, R.G., and J.M. Peek. 1987. Mule deer habitat selection patterns in northcentral Washington. J. Wildl. Manage. 51:46-51.

Clary, W.P., and P.F. Ffolliot. 1966. Differences in herbage-timber relationships between thinned and unthinned Ponderosa pine stands. USDA Forest Serv. Res. Note RM-74.

Freddy, D.J.1985. Quantifying capacity of winter ranges to support deerevaluation of thermal cover used by deer. Colo. Div. Wildl. Wild. Res. Rep. July:13-19.

Gilbert, P.F., O.C. Wallmo, and R.B. Gill. 1970. Effect of snow depth on mule deer in Middle Park, Colorado. J. Wildl. Manage. 34:15-23.

Gilmer, D.S., S.E. Miller, and L.M. Cowardin. 1973. Analysis of radiotracking data using digitized habitat maps. J. Wildl. Manage. 37:404-409.

Gillingham, M.P., and F.L. Bunnell. 1985. Reliability of motion sensitive radio collars for estimating activity of black-tailed deer. J. Wildl. Manage. 49:951-958.

Hanley, T.A. 1982. The nutritional basis for food selection by ungulates. J. Range Manage. 35:146-151.

Hanley, T.A. 1984. Habitat patches and their selection by wapiti and black-tailed deer in a coastal montane coniferous forest. J. Appl. Ecol. 21:423-436.
Harestad, A.S. 1985. Habitat use by black-tailed deer on northern Vancouver Island. J. Wildl. Manage. 49:946-950.

Hobbs, N.T., and R.A.. Spowart. 1984. Effects of prescribed fire on nutrition of mountain sheep and mule deer during winter and spring. J. Wildl. Manage. 48:551-560.

Jennrich, R.I., and F.B. Turner. 1969. Measurement of non-circular home range. J. Theor. Biol. 22:227-237.

Kufeld, R.C., D.C. Bowden, and J.M. Siperek, Jr. 1987. Evaluation of a telemetry system for measuring habitat usage in mountainous terrain. Northwest Sci. 61:249-256.

Loveless, C.M. 1967. Ecological characteristics of a mule deer winter range. Colo. Dep. Game, Fish and Parks. Tech. Pub. No. 20.

Mackie, R.J.1970. Range ecology and relations of mule deer, elk and cattle in the Missouri River Breaks. Wildl. Monogr. 20:1-79.

Medin, D.E., and A.E. Anderson. 1979. Modeling the dynamics of a Colorado mule deer population. Wildl. Mono. 68:1-77.

Metz, H.E. 1974. Relationship between Ponderosa pine and understory herbage production. MS Thesis, Colorado State Univ., Ft. Collins.

Parker, K.L., and C.T. Robbins. 1983. Thermoregulation in mule deer and elk. Can. J. Zool. 62:1409-1422.

Parker, K.L., C.T. Robbins, and T.A. Hanley. 1984. Energy expenditures for locomotion by mule deer and elk. J. Wildl. Manage. 48:474-488.

Patton, D.R. 1974. Patch cutting increases deer and elk use of a pine forest in Arizona. J. Forest. 72:764-766.

Patton, D.R. 1976. Timber harvesting increases deer and elk use of mixed conifer forest. USDA Forest Serv. Res. Note RM-329.

Patton, D.R., and B.I. Judd. 1970. The role of wet meadows as a wildlife habitat in the southwest. J. Range Manage. 23:272-275.

Sokal, R.R., and F.J. Rohlf. 1981. Biometry, 2nd ed. W.H. Freeman, San Francisco.

Southwood, T.R.E. 1966. Ecological methods. Methuen, London.

Spalinger, D.E., C.T. Robbins, and T.A. Hanley. 1986. The assessment of handling time in ruminants: the effect of plant chemical and physical structure on the rate of breakdown of plant particles in the rumen of mule deer and elk. Can. J. Zool. 64:312-321.

Spowart, R.A., and N.T. Hobbs. 1985. Effects of fire on diet overlap between mule deer and mountain sheep. J. Wildl. Manage. 49:942-946.

Telfer, E.S. 1978. Cervid distribution, browse and snow cover in Alberta. J. Wildl. Manage. 42:352-361. 